\title{
船形山・泉ケ岳火山の最終氷期以降の 大規模地すべり地形
}

\begin{abstract}
八木令子*
要 旨奥羽山脈中部に位置する船形山・泉ヶ岳火山は, 更新世中期頃には火山体の形成が汴ぼ終了 し, その後大規模な地すべりによる侵食が進んだ成層火山である。本論では, 火山地域に発生 する地すべりのタイプと発生条件, 地すべりの発生時期と周辺の地形発達との関係について考 察を行った。

船形山・泉ヶ岳火山周辺には, 規模が大きく層すべりで, 細かく分化していく地すべりと, 厚 い溶岩などの滑り落ちによって形成された比較的規模の小さい地すべりが認められる。また前 者は, 分化の過程でも, ほとんど元の構造が破砕されずに残るタイプと, 圧縮の場に, 本来の 構造が破砕されてできた Pressure ridge などの微地形が形成されるタイプに分けられる。これ らはいずれもキャップロック構造をもつ地域に発生しており、キャップロックをなす岩石の種 類や厚さの違いが，地すべりの形成プロセスや形態的な違いをもたらしたと考えられる。

またこれらの大規模地すべりは，3〜4万年前頃に初期の動きがあり，2３万年前，1 万年前 以降にもかなり大きな動きがあった。

キーワード 船形山, 泉ケ岳, 大規模地すべり, 地すべりのタイプ, 地すべり発生条件, 地すべ り発生時期, キャップロック構造, 最終水期
\end{abstract}

\section{I.はじめに}

\section{1. 研究の目的}

湿潤温帯の山地に和ける地形形成営力として，地 すべり・山崩れ等の崩壊現象の重要性が注目されて いる(守屋, 1972 ; 寺戸, 1978 ; 宮城, 1979 ; 町田, 1984 ; 守屋, 1987 他)。すなわち, イランのサイド マーラー (Saidmaareh) の例にも示されるように, 大規模な崩壊現象のなかには, 山頂部をも破壞し, 崩 壊土量が $10^{10} \mathrm{~m}^{3}$ に達するものもあり(町田，1984）, 崩壊が一旦発生した場合の山地地形解体に果たす役 割が極めて大さいからである。

崩壊現象のらち地すべりに関しては, 地すべり地 形の地理的分布に認められる特色を明らかにするこ

* 千葉県立中央博物館
とによって，地すべりの発生のメカニズムを解明す ることを目的として，広範囲を対象に多くの分布図 が作成されてきた（Yamaguchi ed. 1980 ; 国立防災 科学技術センター, 1982 他)。それらの結果, 従来考 觉られていよりもはるかに多くの地すべり地形が 分布することや, 地形・地質条件との対応がみられ ることが明らかにされた。藤田（1982）は，日本列 島は, 第四紀にはいって隆起量が $1,000 \mathrm{~m}$ 以上に達 する地域が広範囲でみられ，このよらな地盤変動が 激しい地域に地すべりや崩壊が発生していると述べ ている。また清水（1985）も，東北地方で第四紀に 打ける隆起量が最も大きいと推定される地域（最大 約 $1,000 \mathrm{~m}$ ), すなわち奥羽山脈中部や白神山地, あ るいは出羽山地南部などで地すべり分布密度が高い ことを指摘している。これらの地域は，地質的には 主に第三系, 特に中新世前期・中期堆積岩および海 
成火山岩類（大八木ほか 1981）で構成される山地丘 陵地(グリーンタフ地帯)，和よびグリーンタフを基 盤として発生する第四紀火山にあたる。奥羽山脈の 船形山や焼石岳などの第四紀火山に沶いても, 山頂 部から山麓にかけて, 移動量が $10^{8} \mathrm{~m}^{3}$ に達する大規 模な地すべりが多数発生している（木全，1983）。

このような，火山体の解体に大きな役割を果たし ていると考觉られる地すべりに関しては，守屋 （1980，1985），古谷 (1983)，清水（1985）などによっ て, 形成プロセス, 形態, 発生条件などで特徵づけ られるいくつかのタイイプがあることが指摘されてい る。また火山体は，テフロクロノロジーの手法がう まく適用できれば，直接的な年代資料を組み込むこ とによって, 非火山地域に比べて地すべり発生時期 の限定がしやすい（清水，1985）とも言われている。 しかし地すべりのタイプや発生時期を, 現実の火山 体の中で具体的に示した例はない。また山体にみら れる地すべり地形には, 様々なステージの現象が混 在していることが喼められるから，それらを一括し て研究することには無理がある。従って当面は, 独 立したひとつの山体に発生する地すべり地形の形成 プロセスと発生条件との関連性, 主要な活動の時期 とその要因などを明らかにする事例研究の蓄積が必 要であると考光る。

本論では, 大規模な地すべりが多数発生する東北 地方の第四紀火山地域のうち, 奥羽山脈中部に位置 する船形山・泉ヶ岳火山にみられるいくつかの地す ベり地形について，その形態や形成プロセス，発生 時期などを記載し，それを基に火山体の解体に関わ る地すべりのタイプと発生条件, 地すべりの発生時 期と周辺の地形発達との関係について考察を行っ た。

\section{2. 研究の方法}

はじめに代表的な大規模地すべり地形について， $1: 7,000$ の大縮尺空中写真の判読によりその微地形 構成 (木全・宮城, 1985)を明らかにし, 地すべり運
動特性把握の予察図を作成した。これの目的は, 微 地形を，地すべり地形の形成過程や，地すべり活動 の結果再編成された構成物質の形態的反映として認 識する点にある。たと党ば，移動物質によって形成 される「地形的高まり」は, 地すべり地の形成過程 復元の有効な指標となることが予想されるため, そ れが引張応力によって形成された Block であるか， あるいは圧縮の場にでさる構造の著しく破碎された Pressure rideであるかなどを，それぞれの微地形に 対応する形態的特徵や配列のパターンを念頭に招 き，厳密に分類した。次にこれを基に現地調查を行 い, 微地形とその内部構造, すべり面の発見などに 努め, 地すべりの運動様式, 活動の歴史の復元を試 みた。な扣これによって特定された運動様式の名称 および概念は，Varnes $(1958,1978)$ に従った。

地すべりの発生時期に関しては，地すべり地内の 微地形分類をもとに，木片などの年代試料の採取地 点と微地形単位との位置的関係を勘案し，それが初 生地すべりに対応するものなのか，二次的な動きに 対応するものなのかを考察した。大規模な地すべり は，初生地すべりの発生から，破壞・移動の完全な 終了までに長い形成期間をもつことも予想できる。 従ってただ 1 点の年代試料の久で, 地すべりの形成 史を語ることがでさないのは言うまでもない。また 本稿では地すべり面の層準と周辺の段丘面との層位 関係，テフラなぞ総合的な資料を用いて，地すべり の発生時期・活動期間を考察することにも努めた。

\section{II. 船形山・泉ヶ岳火山周辺の地形・地質}

調查地は奥羽山脈中部に位置し, 標高 $1,500 \mathrm{~m}$ の 船形山を最高峰とする船形火山群, 泉ヶ岳火山群, 沶 よび七ッ森，薬萊山などの多くの山体を含む（第 1 図)。船形山・泉ケ岳火山の地形・地質学的研究は, 小倉（1921），村山（1973），山野井（1989）などの 報告があり，西村・宮城（1976）は，空中写真判読 と野外調查により, 溶岩流の地形面分類と火山噴出 

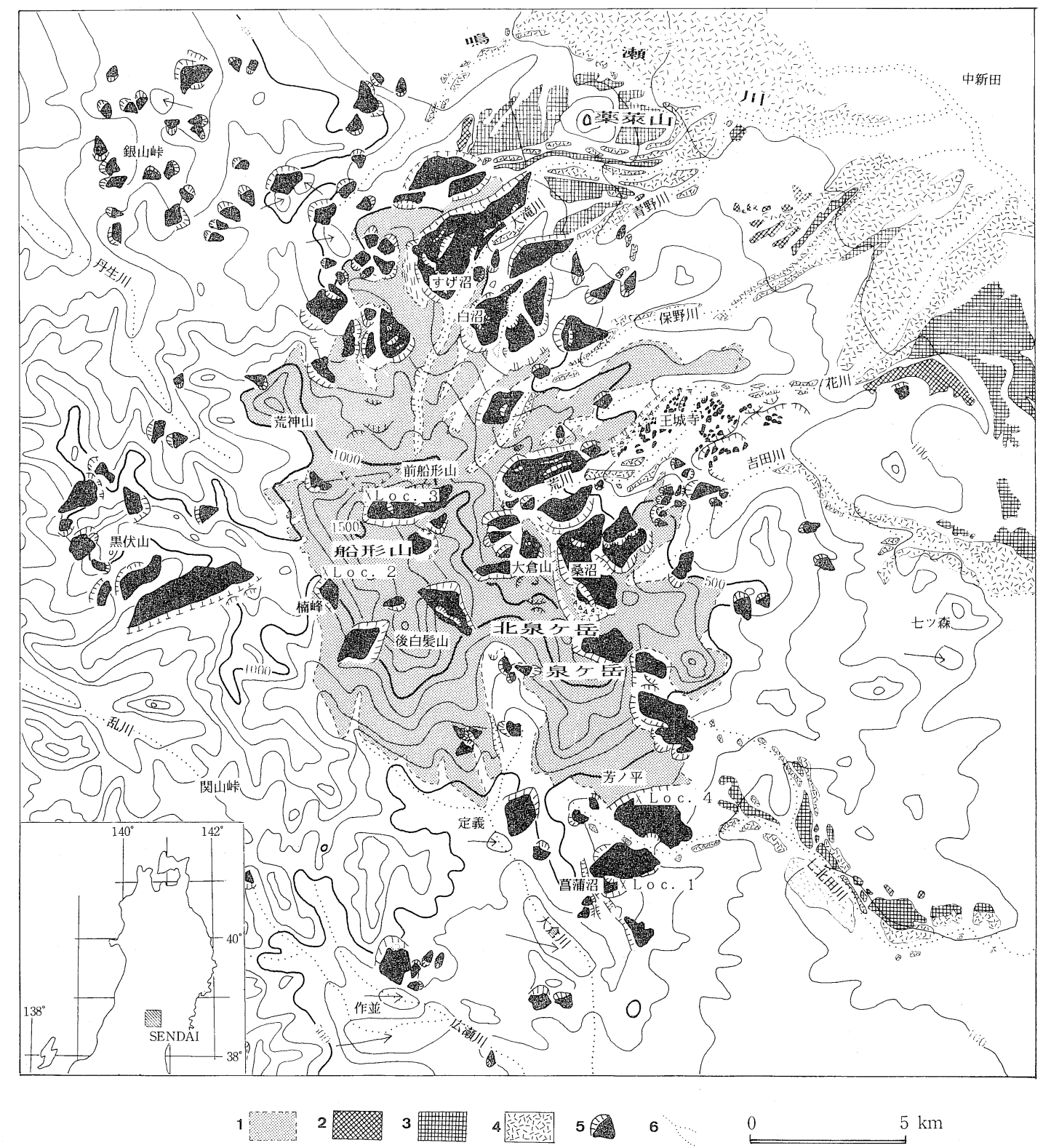

第 1 図 船形山・泉ヶ岳周辺の地形と大規模地すべり地形の分布

1 第四紀火山（西村・宮城 1976） 2 高位段丘面 3 中位段丘面 4 低位段丘面

5 大規模地すべり 6 水系

段丘区分は北村㴗か（1983），Toyoshima（1986）を参考に加筆

コンターは, $500 \mathrm{~m}$ 幅の埋谷接峰面（西村・宮城 1976 による）

Fig. 1 Topography and distribution of large landslides in and around Mt. Funagata and Izumigatake.

1 Quaternary volcano (after Nishimura • Miyagi 1976) 2 upper terrace 3 middle terrace 4 lower terrace 5 large landslide 6 rivers

2-4 refer to Kitamura et al. (1983) and Toyoshima (1986)

restored contour (less than $500 \mathrm{~m}$ ) after Nishimura • Miyagi (1976) 
物の層序を組み立てている。今田・大場（1989）は, 船形・泉ケ岳火山群溶岩の噴出時期について $\mathrm{K}-\mathrm{Ar}$ 法による年代測定を行い，泉ヶ岳火山は約 120 万年 前, 船形山本体は 80 60 万年前に活動したことを明 らかにしている。これらのことから両火山群の形成 は，更新世中期頃末でにはほぼ終了していたと考壳 られる。なた有史時代の活動は記録されていない。 船形山・泉ヶ岳火山を開析する河川としては，第 1 図に示すように, 鳴瀬川, 大滝川, 青野川, 保野川, 花川，吉田川，七北田川，大倉川，丹生川，乱川な どがある。北東側に流下する河川には，上流部から 山麓部にかけて段丘面が連続し, とくに山麓には, 扇
状地性の広い段丘が発達する。溶岩流による緩斜面 は, 大倉川と丹生川を結ぶ線より北東側に集中する。 これは基盤隆起の中心が船形火山群よりも西側に あったか，大きな断層(相対的に西側が隆起)によっ て西側への流下を遮断されたためと考学られている （西村・宮城，1976）。

火山体の中軸から東側の基盤は，主に鮮新世の凝 灰岩，浮石質凝灰岩，凝灰質シルト岩，凝灰角碩岩， 砂岩などで, 標高 800 1,000 m 程度にまで達してい る。その上にのる火山噴出物は, 溶岩, 火砕流堆積 物, 泥流などであるが，その 1 枚 1 枚は薄く, 1 枚の 溶岩の厚さもせいぜい 20 〜 $50 \mathrm{~m}$ であると考えられ
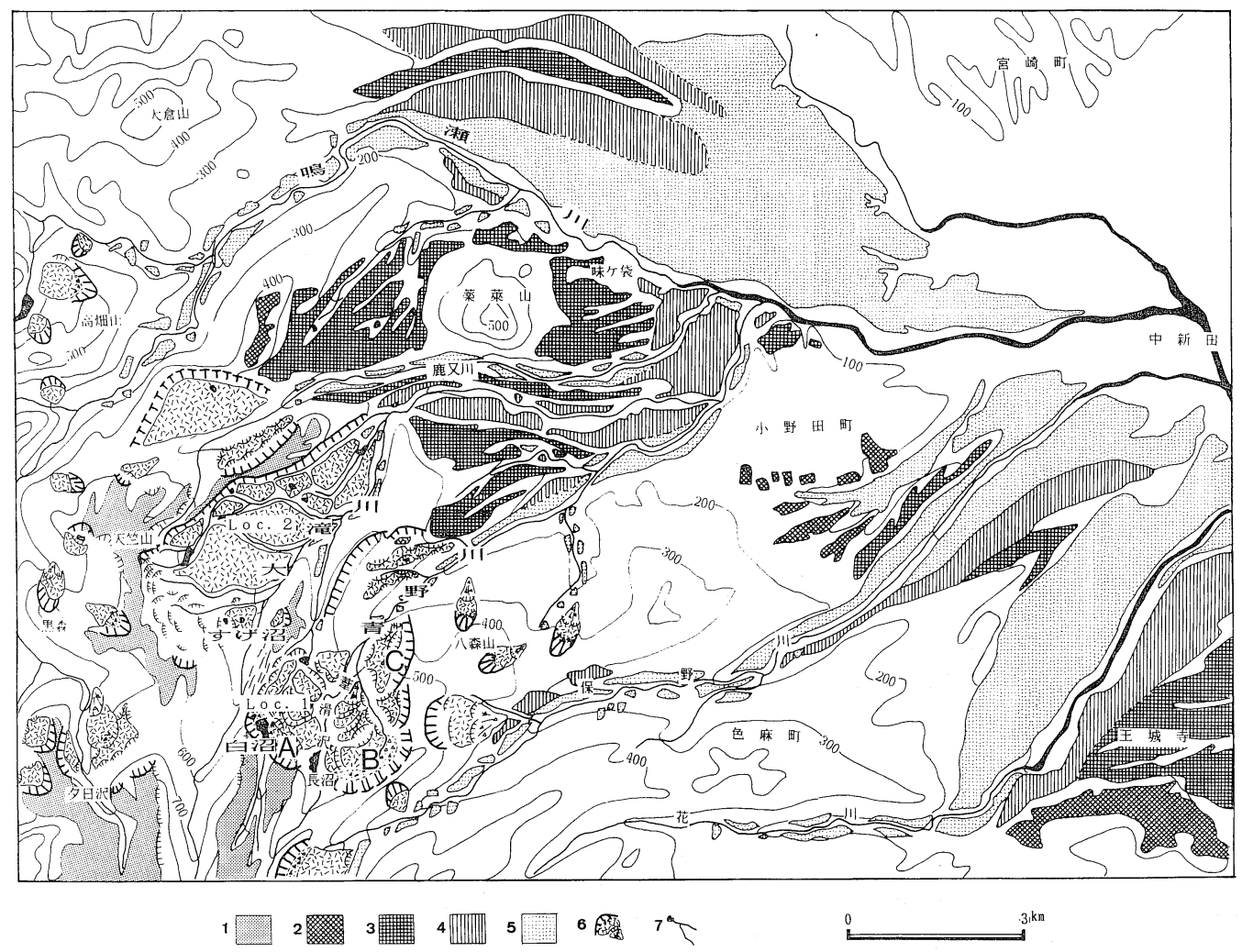

第 2 図船形山北麓の地形と地すべり地

1 溶岩や火砕流による堆積緩斜面 2 高位段丘 3 薬萊面 4 大の原面 5 味ヶ袋面 6 地すべりによって形成された崖とBlock７水系３-5 は Toyoshima（1986）

Fig. 2 Topography and landslides at the northern foot of Mt. Funagata. 1 low relief surface formed by lava flow or pyroclastic flow 2 upper terrace 3 Yakurai terrace 4 Dainohara terrace 5 Ajigafukuro terrace 6 scrarps and blocks formed by landslides 7 rivers $\quad 3-5$ after Toyoshima (1986) 
ている（今田・大場，1989）。山頂部及び山麓部には 数平方 $\mathrm{km}$ にわたる大規模な地すべりが分布して招 り，地すべり及び河川による山体の破壞がかなり進 んでいる。

\section{III. 船形山・泉ヶ岳火山の地すべり地形}

\section{1. 船形山北簏の地すべり地形}

船形山北麓には，船形山起源の火山噴出物や古い 段丘面起源の平坦面を切って, 水平面積が $1 \sim 6 \mathrm{~km}^{2}$ に及ぶ大規模な地すべり地形が多数発生している (第 2 図)。それらのうちほとんどの地すべり地形は, 平坦面を切る顕著な崖と, 一見複雑な大小の地形的 高まりで構成され，周辺の緩斜面とは著しく異なっ た地形を示す。このうち第 2 図 Loc. 1 の白沼及び
Loc. 2 のすげ沼周辺の地すべり地形は，規模もとく に大きく, 船形山北麓の地すべりによる地形形成プ 口セスを明らかにする上できわめて重要であると考 えられる。

\section{1）白沼地すべり地}

白沼地すべり地は，船形起源の火山噴出物を切っ て，海抜 $700 \mathrm{~m}$ 付近から発生し，水系によって大き く3つの地域に分けられる(第 2 図, Loc. $1 \mathrm{~A} \sim \mathrm{C}$ )。 水平面積は $6 \mathrm{~km}^{2}$ である。第 3 図は, 白沼地すべり 地 $\mathrm{A}$ 地域の微地形分類図，抒よび $\mathrm{X}-\mathrm{Y}$ に沿う地形 地質断面である。溶岩流堆積物を切る崖(Loc. 1) は, 西側の一部で湾曲する平面形を呈し，綎断形はほほ 直線状で, 比高 $100 \mathrm{~m}$ 以上, 平均傾斜 $35^{\circ}$ である。こ の崖では，基盤である鮮新統小野田層の塊状半固結

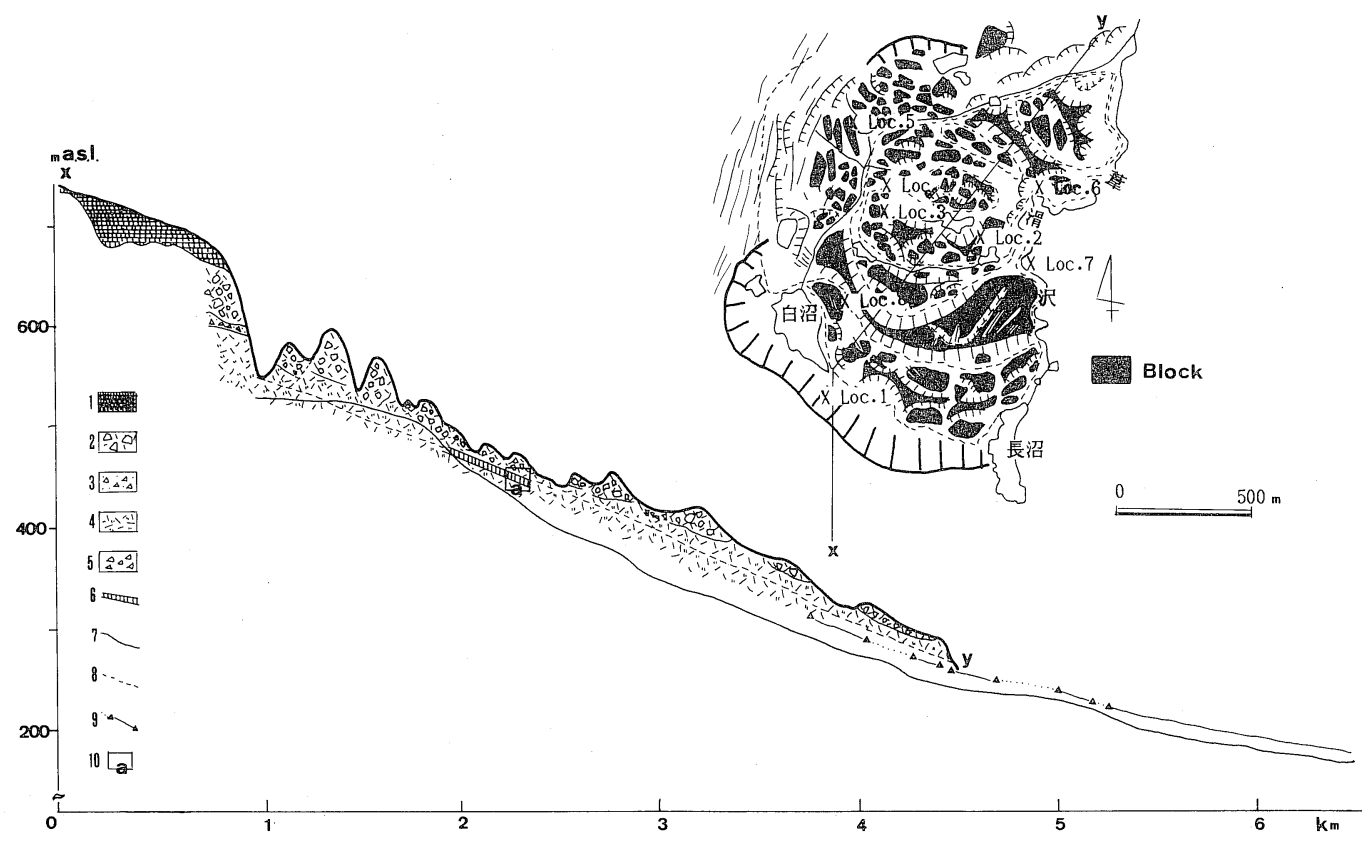

第 3 図白沼地すべり地微地形分類図及び断面図

1 安山岩質溶岩 2 火砕流堆積物 3 泥流堆積物 4 浮石質凝灭岩 5 岩屃

6 細粒 (粘土質) 凝灰岩 7 河床綐断面 8 すべり面 9 味ケ袋面樅断投影位置 10 第 5 図すべり面スケッチ位置

Fig. 3 Micro-landform classification and cross section $(\mathrm{X}-\mathrm{Y})$ of Shironuma Landslide. 1 andesite lava 2 pyroclastic flow deposit 3 mudflow deposit 4 pumiceous tuff 5 debris 6 clay tuff 7 longitudinal profile of river bed 8 slip surface 9 Ajigafukuro terrace 10 location of Fig. 5 
の浮石質凝灰岩が基部に認められ，それは西側白沼 湖岸にむかって露出する高度が上がっている。この 起伏をらめて, 安山岩質の角一亜角䃯（最大礫径 1 $\mathrm{m}, 10 \sim 20 \mathrm{~cm}$ の礫が多い)を主体とし，マトリック スが淡黄色〜灰白色の砂質凝灰岩である火砕流堆積 物が，50〜70 cm の厚さでのっている。また一部に は，マトリックスが火山灰質の泥流状堆積物がはさ まれる。それらの上位には船形山第 1 溶岩（西村・ 宮城，1976）がうすく抒招っている。

この崖の前面は，白沼を含先幅 100 200 m の底 面の広い凹地（溝状凹地）をはさんで移動域となる。 移動域はさまざまな規模の崖と多数の地塊によって 構成され，各地塊間は相対的な凹地となっている。各 地塊は，やや規模が大きく concave な崖で囲まれる ものと(第 3 図 Loc. 2 など)，小規模で convex な斜 面形をもつものとにわけられるが(Loc. 3〜 5 など), いずれもそれらに接する斜面とは明瞭な傾斜変換線 で境される。Loc. 2 で観察された地塊の構造は，基 盤の上に火确流堆積物がのり,それらは破砕されず, 転位もしていない。交たLoc. 3〜 5では, 基盤の小野 田層之考方られる未風化の浮石質凝灰岩が観察され る。このように地塊は注とんど破壞されて扮らず，ま た転位もあすり顕著でないことから，引張応力に よって形成され，層すべりで移動した Blockである と考光られる。机た Loc. 1 の崖と Block の間には溝 状凹地が認められることも考光併せて，これらの Block は，全体として崖から分離して移動したもの と思わ机る。そこで Block 間の凹地の底面高度を連 㱛ることにより，第 3 図の断面図に示すような直線 状のすべり面（glide）を想定し，これに相当する位 置を観察した結果，実際に以下に示すようなすべり 面の存在が確認された。

すなおち第 3 図 Loc. 6 の蕫滑沢の河床付近には, 北にゆるく傾く小野田層の浮石質凝灰岩中に，厚さ 数 $\mathrm{m}$ の細粒の凝灰岩が挟在しているのが観察され る。また Loc. 7 の地点では，上位の火砕流堆積物と

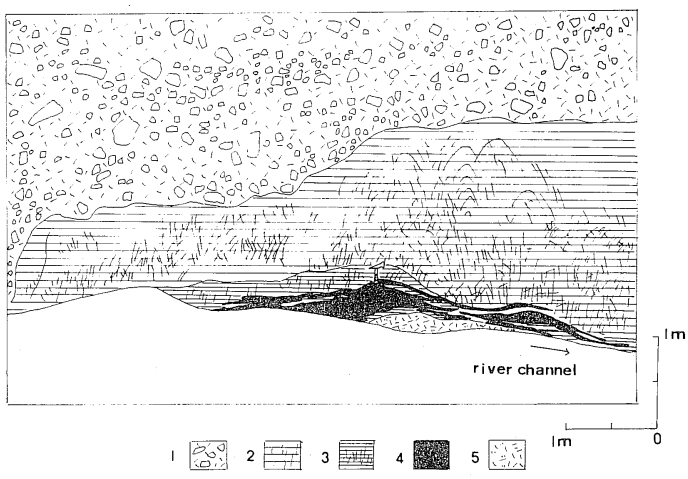

第 4 図 蔁滑沢に沿うすべり面スケッチ 1 火砕流堆積物 2 凝灰質頁岩 3 細粒 (粘土質) 凝灰岩 4 粘土 5 浮石質凝灰岩

Fig. 4 Sketch of slip surface along Ashinamesawa, Shironuma Landslide.

1 pyroclastic flow deposit

2 tuffaceous shale 3 clay tuff

4 clay. 5 pumiceous tuff

基盤の浮石質凝灰岩の間に細粒の凝灰質頁岩が認め られるが，それらは破砕され，その下部が著しく揉 まれて粘土化している(第 4 図)。その一部は黄褐色 に変色し，ルーズな層準となって抢り，この粘土化 した層準はすべり面に相当すると思われる。すべり 面形成に伴う破砕は, 凝灰質頁岩の部分も含めると, 数 $\mathrm{m}$ に及ぶ。莘滑沢沿いで観察されたすべり面はこ の 1 ケ所であるが，この位置を第 3 図の断面上に投 影すると，注ぼ地形から推定したすべり面上にのる。

ところで移動域を構成する微地形は，一見不規則 に配列しているようにみえるが，崖を同程度の規模 ごとにまとめてみると，4つの階層にわけることが できる。また concave な崖で囲まれる Block は，よ り大きなBlock が分化した結果残された名残りの 地形と考光ることができるので，これらの地形を基 に，それぞれの階層の崖に対応した Blockを復元 し，規模の大きいものから並へ(第 5 図，1４），次 のような規則性を見いだした。すなわち第1段階は， 初生地すべりに伴う崖と, それに対応する Block が 表現されたものと考光られ，この段階で地すべり活 動の及ぶ範囲が潘济限定される(1)。第 2 段階は，そ 

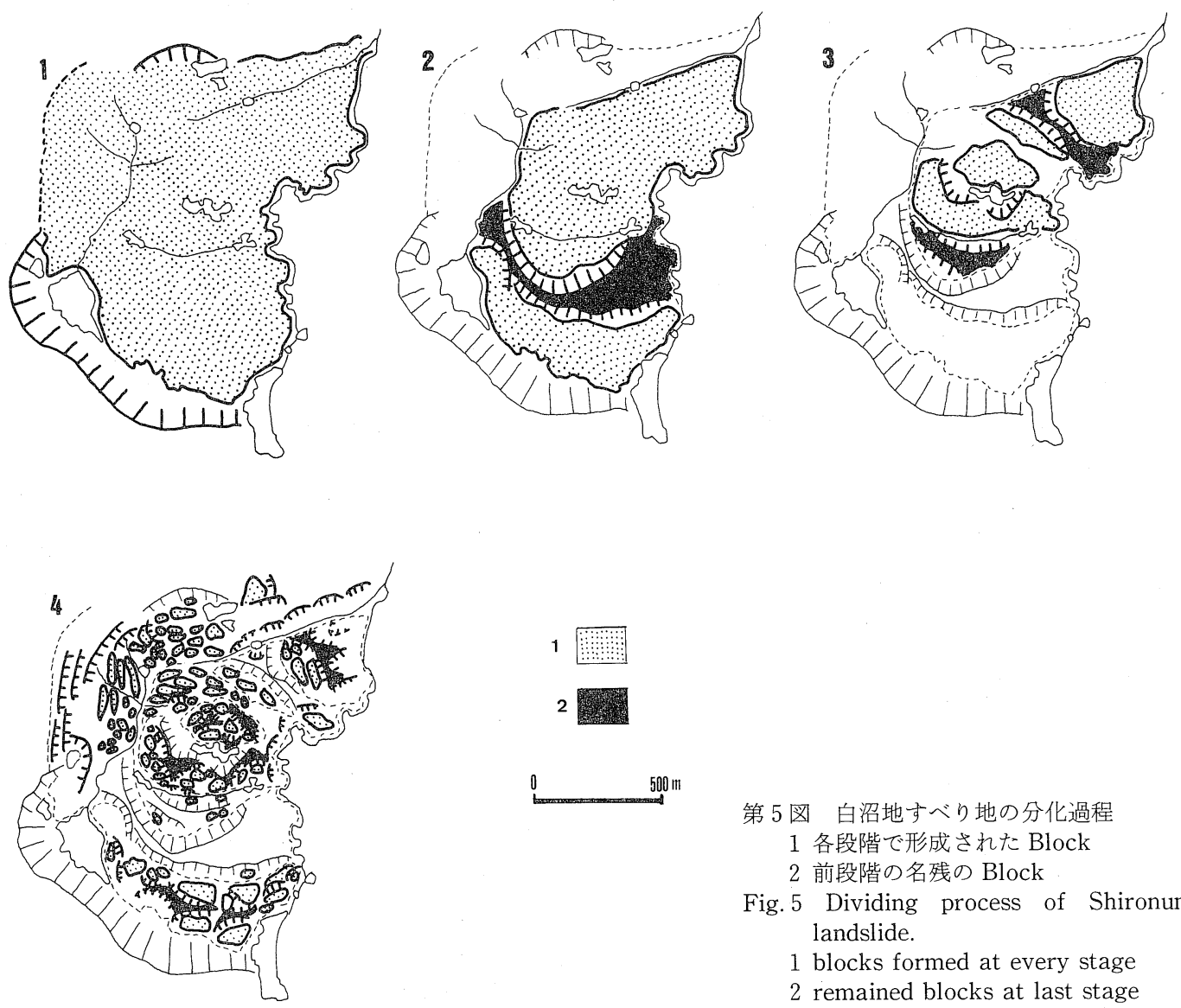
第 5 図 白沼地すべり地の分化過程
1 各段階で形成された Block
2 前段階の名残の Block

Fig. 5 Dividing process of Shironuma landslide.

1 blocks formed at every stage

2 remained blocks at last stage

のBlock が移動方向と逆向きとに分化した結果形 成された崖とBlock 预よび前段階の名残りの地形 が表現され，移動域は細分される(2)。第 3，4 段階 も，同じように前段階の Block が分化していく過程 で形成された崖とBlockに対応している。現在の白 沼地すべり地の地形は，最終的に分化した Block と,より高次の Blockの名残りの地形が混在してい ることになる。以上のような地塊の分化は, 結果的 にこの地すべり地形の発達過程を示しているものと 考えられる。ただし各階層は, 崖とBlockの規模の 等しいものの集合であり，必ずしもBlockの分化す る時期の同時性を示しているのではない。

以上から次のよらな形成プロセスを考觉る。まず 初生地すべりの段階では, Block 間の凹地の底面高
度の下限を連ねることによって想定した，傾斜約 $5^{\circ}$ の直線状のすべり面に沿って, 第 5 図 1 のような大 規模な Block が，溶岩の末端を切って分離した。そ の後第 5 図 2〜4 に示すよらに, 各 Block はそれぞ れの段階で，逆向きを含む様々な方向に，構造をほ とんど破砕することなく分化していったものと考光 られる。すべり面は地層の傾斜方向とほぼ調和的で, 流れ盤の地質構造に発生する地すべり, すなわら層 すべりであると思われる。

白沼地すべり地からは, 初生的な地すべりの発生 を直接示すよらな年代は得られていないが，大規模 な Block に対応する位置（第 3 図 Loc. 8) に，約 1 万年前に降下したと考它られる（米地・菊地，1966） 尾花沢軽石層が成層しているのが観察され，小規模 
なBlock にはそれらは認められない。これらのこと から, 主要な活動の時期は尾花沢軽石層降下以前で (約 1 万年前以前), 降下後子移動は継続し, その過 程で表層の堆積物は消耗してしまったと考光る。ま た白沼地すべり地全体をみると, 東側の部分(第 2 図 B)は，Aの部分よりも開析が進み，より古い時期に 形成されたものと考えられ，地すべりの初期の動き

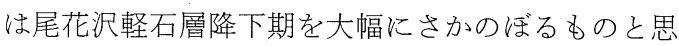
われる。このことについて星埜（1981）は，周辺の 段丘面を立川面に対比されるものとしたら党で, 段 丘面と地すべり地形との関係から，白沼地すべりの 形成は，立川面相当面形成期には活潘終了していた と述べている。

\section{2）すげ沼地すべり地}

すげ沼地すべり地は，海抜 400～650 m に広がる 段丘面起源の平坦面を切って，大滝川上流にむかっ て, 水平面積約 $6 \mathrm{~km}^{2}$ の規模で発生している（第 2 図 Loc. 2)

第 6,7 図は,すげ沼地すべり地の微地形分類およ
びX-Y に沿う地形地質断面である。段丘面起源の 平坦面を切る崖は, 南西一北東に長さ $2 \mathrm{~km}$ にわ たって, $50 \mathrm{~m}$ 前後の比高と, $40^{\circ}$ 前後の傾斜を保ちな がら連続する。その縦断形は直線状である。崖を構 成する地質は，下位より緻密で半固結のシルト質凝 灰岩を主体とする凝灰岩層（鮮新統小野田層相当）, その上位に船形火山起源と思わ机る凝灰角礫岩, 段 丘堆積物, 火砕流堆積物が載る。地すべりは, 小野 田層の凝扊岩層の上部から発生している。この崖の 地層は, 大滝川右岸の不動域の地層にある程度対応 し，崖の下方の凝灰岩層は，見かけ上厚さを減じな がら大滝川側に低下している。従って地層の全体の 傾斜方向はごく緩い南東落ちとなる。大滝川沿いの 第 6 図 Loc. 1 の地点では, 粗粒な凝灰岩の下に, 亜 炭を伴ら凝灰質頁岩が認められる。その一部は灰 一褐色の柔らかい粘土となり, 周辺の層準は著しく 破砕されていることから，すべり面の一部と考光ら れる。

移動域は, 水系によっていくつかの平板な地塊に

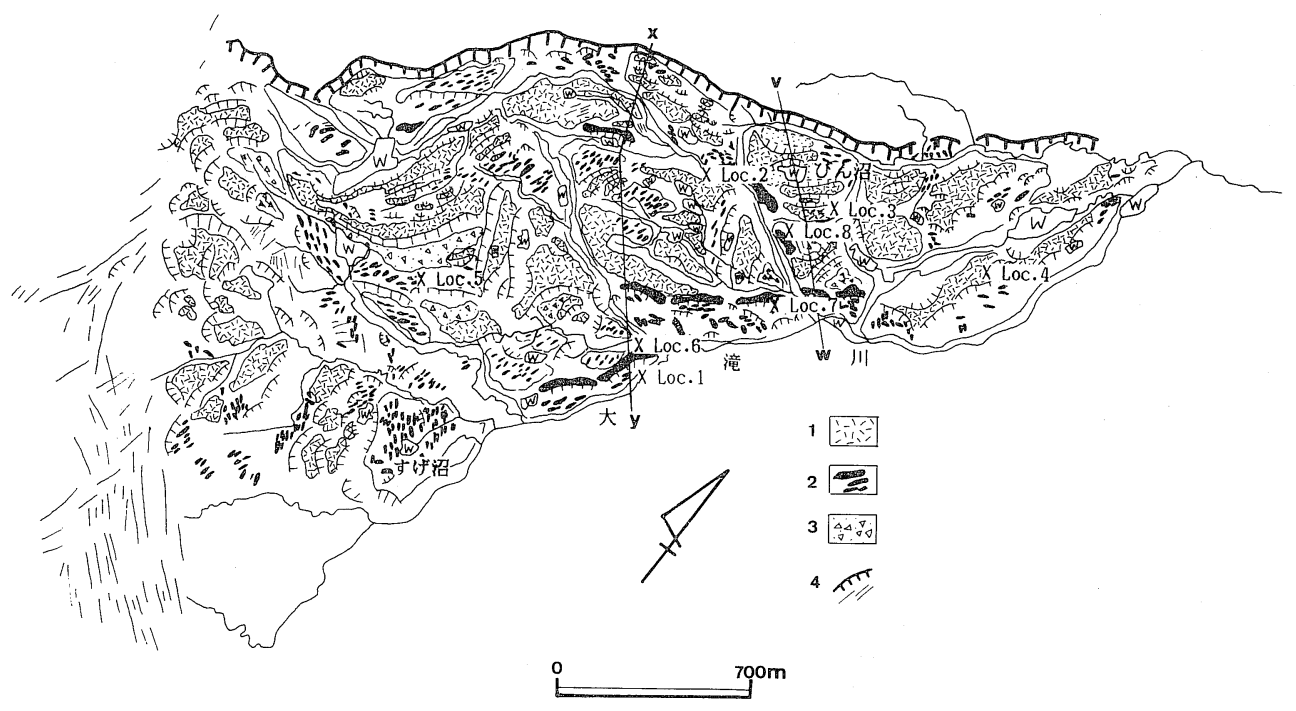

第 6 図すげ沼地すべり地微地形分類図

1 Block 2 Pressure ridge 3 岩屑 4 崖とクラック

Fig. 6 Micro-landform classiffcation of Sugenuma landslide.

1 block 2 pressure ridge 3 debris 4 scarp and crack 


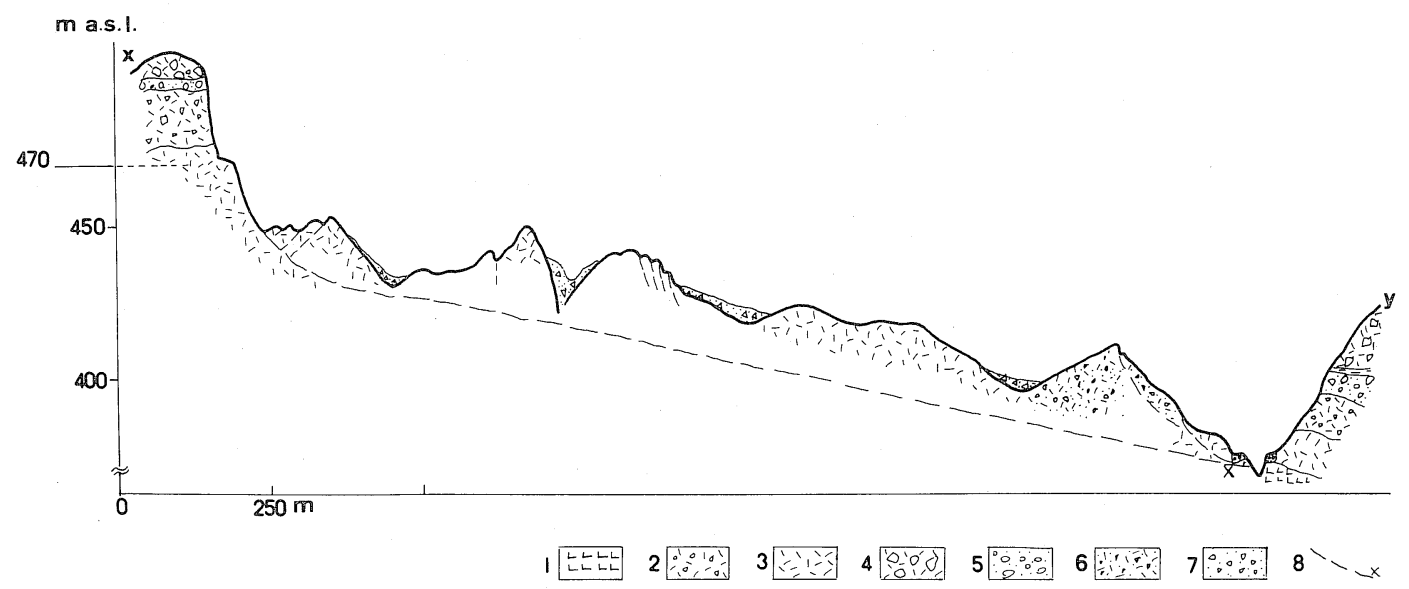

第 7 図 すげ沼地すべり地縦断面図 (X-Y)

1 集塊岩 2 凝灭角碟岩 3 凝灰岩 4 火砕流堆積物 5 円碟層 6 凝灰質口一ム 7 砂䃯 8 すべり面

Fig. 7 Cross section of Sugenuma landslide (X-Y).

1 agglomerate 2 tuff breccia 3 tuff 4 pyroclastic flow deposit 5 round gravel layer 6 tuffaceous loam 7 sand and gravel 8 slip surface

分割されている(第 2 図)。北東側の地塊はさらに明 瞭な崖を伴い，表面がほとんど乱されていない高ま りに分割されている(第 6 図 Loc. 2〜4など)。この うち Loc. 2 の高まりは, 平坦面を切る崖の下方で認 められた凝死岩層で構成され, それらは汪とんど破 砕されていないことから，1 つの Blockであると思 われる。

一方, 南西側の地塊上には, 小規模な崖や不規則 な高をりが多数認められ，全体として波状の地形を 呈する(第 6 図 Loc. 5 など)。これらは安山岩や凝灰 岩の小角碩含含, 泥質一凝灰質口ームで構成され， 著しく破研されている。また移動域全体にわたって, 平板な地塊の境界部や大滝川沿いには，規模の大き な長円形の convex な斜面形をもつ高をりがみられ る(Loc. 6〜 7など)。このうち Loc. 6 の高李りは泥 質〜砂質口ームで構成され, 凝死岩やシルト岩の岩 塊, 安山岩や凝灰岩の角碩を含む(第 8 図)。ローム の上部には, 先に述べた尾花沢軽石層をはさみ, さ らに砂質ロームが薄く広がる。この軽石層は成層し ているところもあるが, 転位したり, 下位の地層に
巻き込まれた部分もある。これらのことから Loc. 5 の波状地形やLoc. 6 の高まりは, 圧縮の場に形成さ れる Pressure ridge であると考兄られる。従ってす げ沼地すべりの移動域には, 張力下の Block と圧縮 によるPressure ridge が混在していることが分か る。

次にすげ沼地すべり地の運動様式および形成プロ セスを推定する。第 9 図は, 第 6 図 V-W に沿う地形 地質断面である。ここでは直線状の崖の前面に, 幅 $100 \mathrm{~m}$, 長さ $180 \mathrm{~m}$ の溝状凹地を挟んで, 幅 $40 \mathrm{~m}$, 長

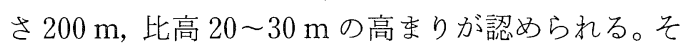
の前面にも同じ位置関係で, 凹地と高末りが交互に 連続する。これらの高委りを構成する地質は, 崖を 構成するそれと比較して層準, 構造ともに泀とんど 変化, 変質がみられず, 転位もしていない。従って これらの地塊は, 直線状のすべり面に沿って, 崖の 位置から分離し移動してきたものと思われる。すべ り面の傾斜は南東落ち約 $4^{\circ}$ で, 周辺の地層の傾きと ほぼ調和的である。

従って本地すべり発生の初期の段階では, 細粒の 

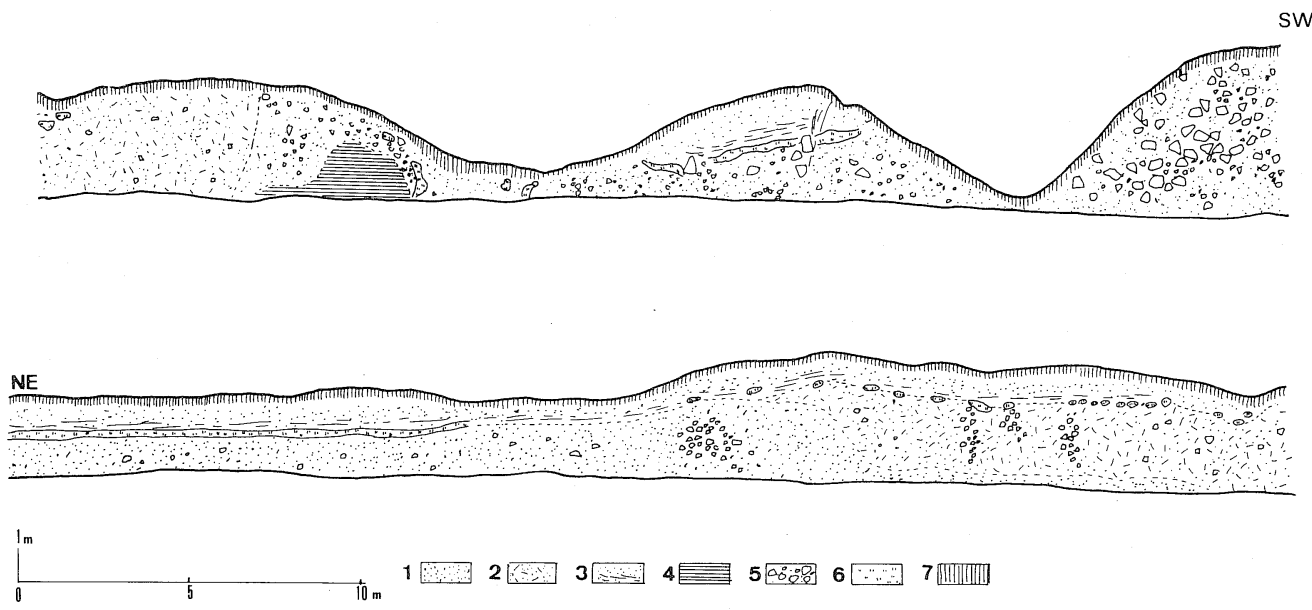

第 8 図 すげ沼地すべり地の大規模な Pressure ridgeのスケッチ

1 砂質ローム 2 凝灰質砂質ローム 3 ラミナのはいった砂質ローム 4 細粒(粘土質)凝

灰岩 5 角礫 6 尾花沢パミス 7 腐植層

Fig. 8 Sketch of large pressure ridge, Sugenuma landslide.

1 sandy loam 2 tuffaceous sandy loam 3 sandy loam lamina 4 clay tuff

5 angular gravel 6 obanazawa pumice 7 black humus

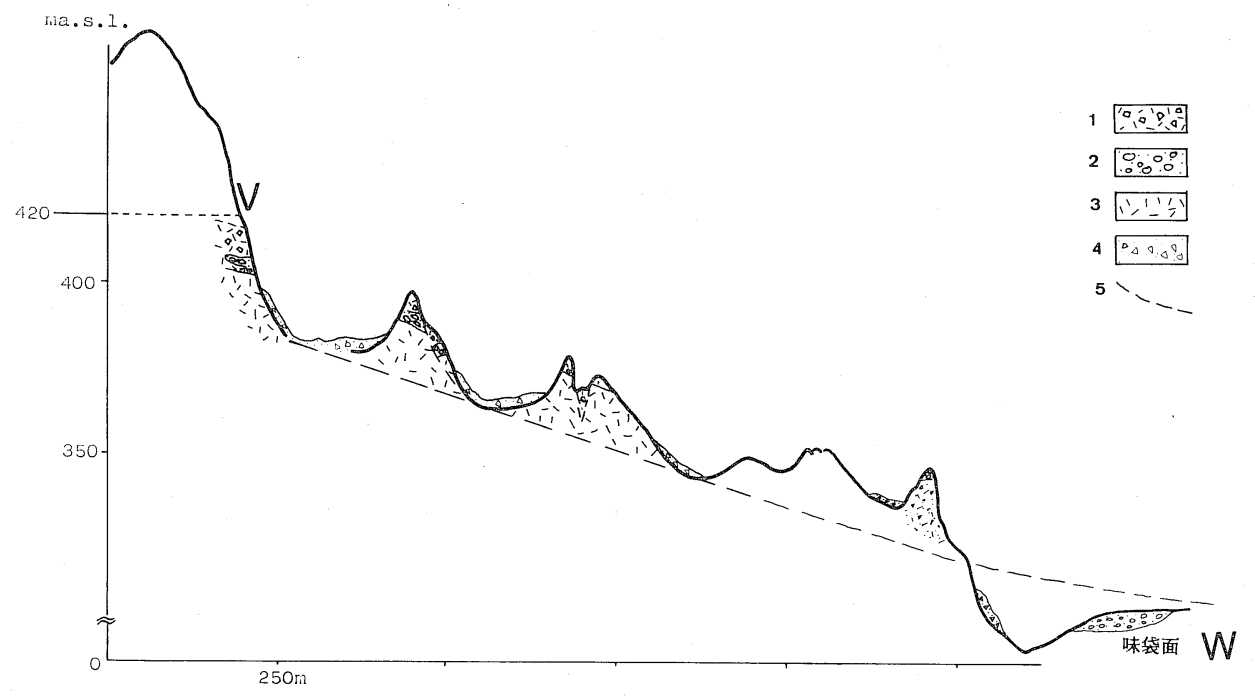

第 9 図すげ沼地すべり地縦断面図 $(V-W)$

1 火砕流堆積物 2 円䃯層 3 凝灰岩 4 岩屑 5 すべり面

Fig. 9 Cross section of Sugenuma landslide $(\mathrm{V}-\mathrm{W})$.

1 pyroclastic flow deposit 2 round gravel layer 3 tuff 4 debris

5 slip surface 
凝灰岩をすべり面として層すべり的に移動し，いく つかの平板な地塊が形成されたものと考光られる。 次いでこの地塊がさらに分化してより小さなBlock が形成された。その際, 地塊の境界部や地すべり地 の末端部などでは, 移動に伴う Block 同志の示差的 な動さによって形成された圧縮の場に，小規模な Pressure ridgeの連続した波状地や長円形の Pressure ridge が形成されたものと考光る。

一方, 地塊の境界部の Pressure ridge の一部（第
6 図 Loc. 8) では，基盤の凝灰岩層が $2 \sim 3 \mathrm{~m}$ 大の岩 塊に分割され，それらが不規則に堆積し，礫や樹木 を取り込んでいるのが観察された。木片の ${ }^{14} \mathrm{C}$ 年代 は, 34,500 年前以前 $(\mathrm{TH}-917)$ と測定され，初期の 地すべり活動が最終水期中頃に遡ることを示してい る。また Loc. 6 の高まりの堆積物中には, 約 1 万年 前の堆積とされる尾花沢軽石層が，一部もまれて立 ち上がって扮り，1万年前以降にも大きな動きが あったと考兄られる。微地形を構成する小崖には極

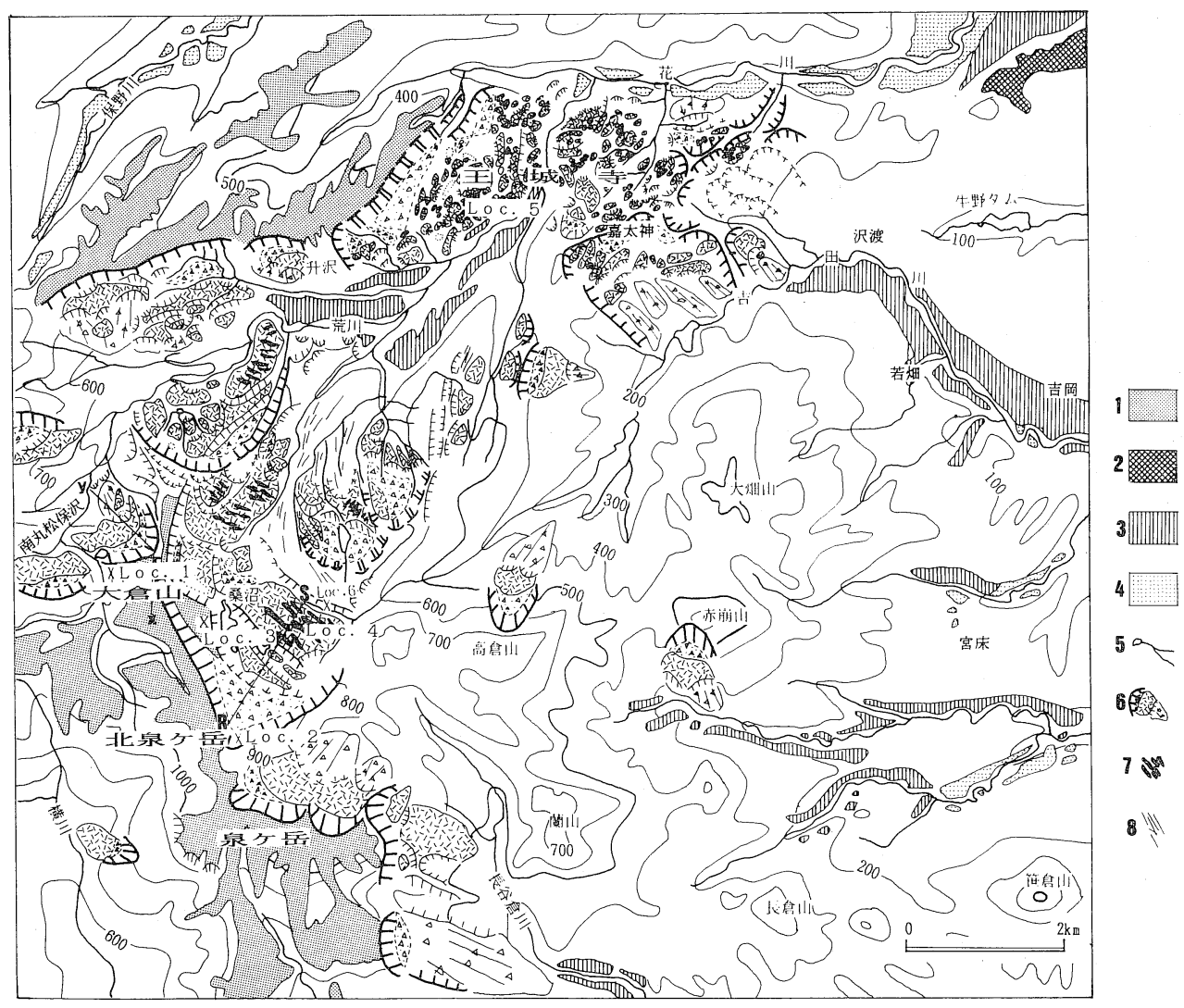

第 10 図北泉ケ岳周辺の地形々地すべり地

1 溶岩や火砕流による堆積緩斜面 2 高位段丘面 3 中位段丘面 4 低位段丘面

5 水系 6 地すべりによる崖と Block 拈よび流れ山状の地形 7 Pressure ridge

8 クラック

な抒，段丘区分は北村ほか（1983）を参考に加筆，コンターは $200 \mathrm{~m}$ 幅の埋谷接峰面.

Fig. 10 Topography and landslides in and around Mt. Kitaizumigatake.

1 low relief surface formed by lava or pyroclastic flow 2 upper terrace 3 middle terrace 4 lower terrace 5 rivers 6 scarps and blocks formed by landslides and mudflow hills 7 pressure ridge $8 \mathrm{crack}$

2-4 refer to Kitamura et al. (1983), restored contour (less than $200 \mathrm{~m}$ ) 
めて新鮮な形態を示すものが無数に発達し, 大滝川 沿いの砂防ダムの破壊なども認められることから， 現在も滑動が継続していると考光られる。

\section{2. 北泉ヶ岳周辺の地すべり地形}

北泉ケ岳周辺は, 泉ケ岳扮よび船形山起源の火山 噴出物や溶岩による堆積緩斜面が広がり，それらを 下刻する谷が峡谷部をなし，その縁辺には水平面積 $1 \mathrm{~km}^{2}$ 以下の小規模な地すべり地形が発生してい る。また緩斜面の末端を切って, 水平面積が $5 \mathrm{~km}^{2}$ 前後の大規模な地すべり地形が分布している（第 10 図)。

1）大倉山地すべり地

北泉ケ岳北方大倉山の北西斜面には，南丸松保沢 に向かって水平面積 $0.8 \mathrm{~km}^{2}$ の地すべり地形が認め られる（第 10 図 Loc. 1)。

第 11 図は，大倉山地すべり地の X-Y に沿う断面 図である。北泉ケ岳第 2 溶岩（西村・宮城 1976）な ぞの溶岩流堆積面を切る崖は, 馬蹄形の平面形を呈 し，上部は直線状，下部は凹形の断面形で，平均傾 斜 $40^{\circ}$, 比高は $200 \mathrm{~m}$ 以上に抏よび, 開析は進んでい ない。

地すべり地の主体は, 比高 $60 \mathrm{~m}$ で, 長軸 $800 \mathrm{~m}$, 短軸 $400 \mathrm{~m}$ に打よぶ 1 つの地塊で構成される。地塊 の頂部斜面はゆるやかな凸形で，崖側の斜面は直線 状ないしわずかに凸形な断面形を呈し，溶岩流堆積 面の原面を保存している。この地塊の表面には，斜 面の縦断形を乱すような微小な高まりやクラックな ぞは認められず，溶岩の破砕もほとんどない。これ らのことからこの地塊は単一の Block であると考 学られる。第 11 図に示すように, Block の崖側の斜 面の傾斜 $(\theta 2)$ は約 $5^{\circ}$ で, 北泉ヶ岳第 2 溶岩の原面 の傾斜 $(\theta 1)$ と注汪一致する。このような傾斜の連 続性からみて, Block はかつての北泉ケ岳第 2 溶岩 の原面であり，斜面が崖側に逆傾斜していることか ら, Block の形成に扮いては回転運動(slumping)を 伴っているものと思わ机る。すなわち本地域では, 北

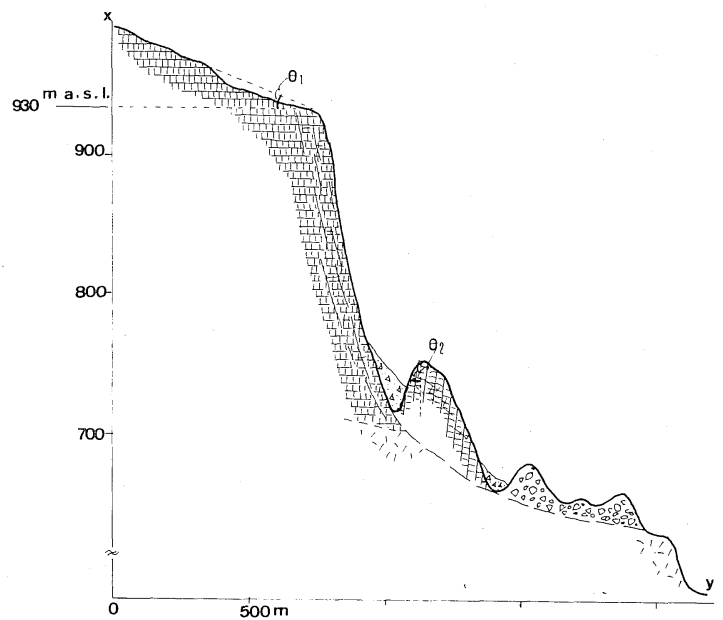

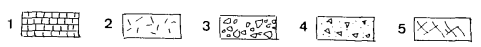

第 11 図大倉山地すべり地綎断面図 (X-Y)

1 安山岩質溶岩 2 凝灰岩 3 二次堆積物 4 岩屑 5 柱状節理

Fig. 11 Cross section of Ohkurayama landslide (X-Y). 1 andesite lava 2 tuff 3 secondary landslide deposit 4 debris 5 columnar joint

泉ケ岳第 2 溶岩の末端が, 単一の大きな Block とし て，急角度の円弧状のすべり面に沿って移動してき たと考学られる。また移動 Block に対して崖の比高 が大きいことから，Block は鉛直的には比較的長い 距離を移動したと思われる。その場合 Block は崖の 比高分の高さをもつはずであるが，実際の断面で、 比高の半分にも満たない。これに関しては, Blockの 下半部が移動時に破砝され，破砕された物質が河川 によって運ばれたためと考えている。

2）桑沼地すべり地

北泉ケ岳の北東斜面（北泉ケ岳第 2 溶岩）は，北 北西から北東に湾曲した比高 300 400 m の馬蹄形 の崖によって切られる（第 10 図 Loc. 2)。この崖の 前面には，南側を崖錐堆積物などで被われた北泉ヶ 岳第 1 溶岩の堆積面がわずかに認められる（Loc. 3)。この堆積面はさらに比高数 $10 \mathrm{~m}$ の崖によって 境され，その前面には凹凸のある微地形が分布する 
緩斜面が広がっている(Loc. 4)。さらに山簏部の王 城寺演習場周辺には，流れ山状の地形がみられる (Loc. 5)。

第 12 図は第 10 図X-Y に沿う地形地質断面であ

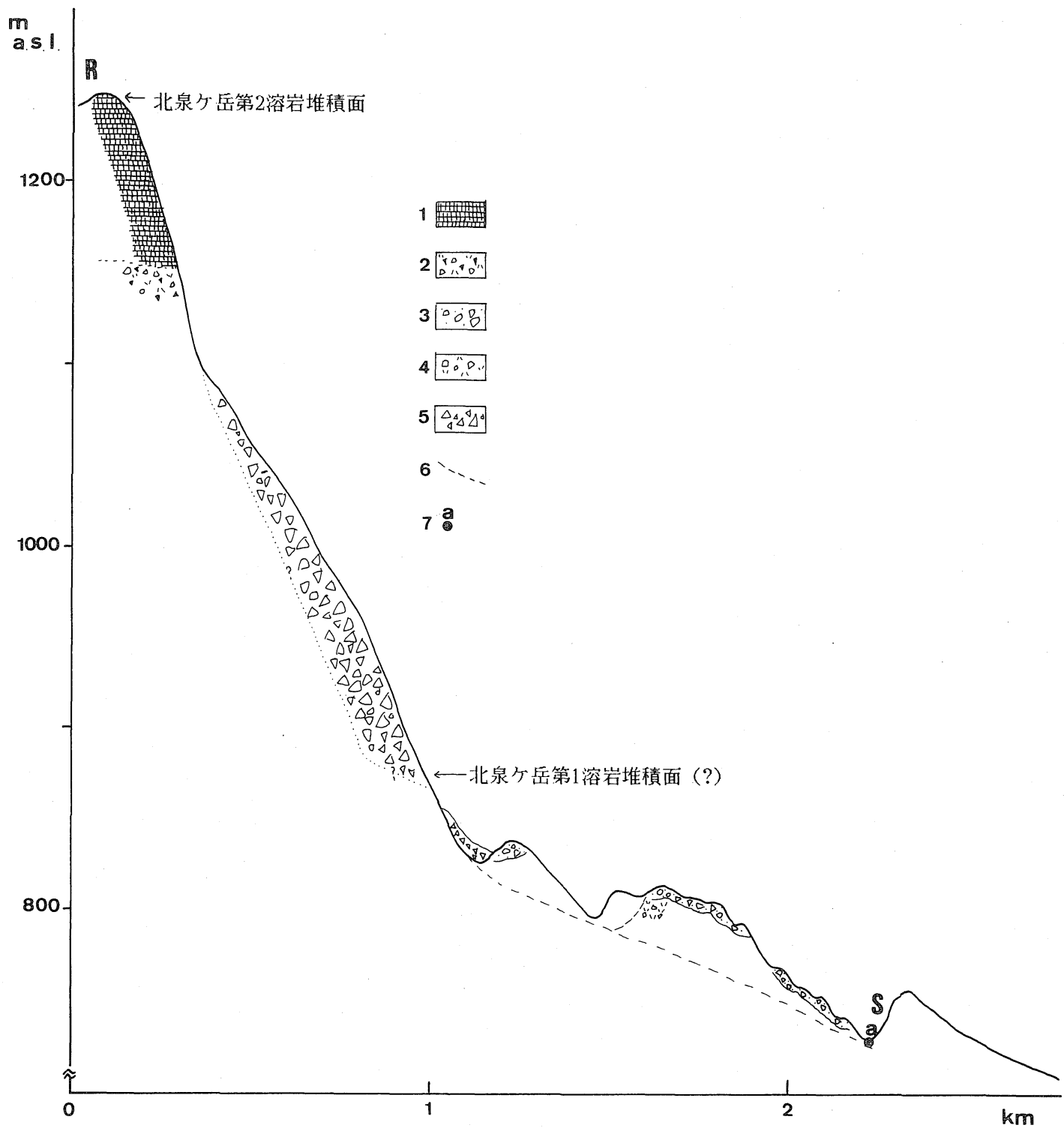

第 12 図桑沼地すべり地縦断面図 (R-S)

1 安山岩質溶岩 2 軽石片を含む㠜灰角砅岩 3 泥流堆積物 4 火砕流堆積物

5 岩屑 6 すべり面 7 すべり面露頭投影位置

Fig. 12 Cross section of Kuwanuma landslide (R-S).

1 andesite lava 2 tuff breccia with pumice 3 mudflow deposit 4 pyroclastic flow deposit 5 debris 6 slip surface 7 location of outcrop of slip surface 
状節理の入った溶岩となっている。下部は崖錐状堆 積物に挆扣われ，崖を構成する地質は観察できない が，海抜 850 900 $\mathrm{m}$ 付近はやや平坦な地形になっ て抒り, 北泉ケ岳第 1 溶岩の堆積面のなごりと推定 される。このあたりから 1 3 m の安山岩の巨碩が 多く認められる。下位の崖の前面は, 桑沼などを含 む幅 200３00 m の溝状凹地をはさんで，逆むきの 崖に囲まれた平板な地塊が認められる。溝状凹地上 にも小規模な地塊が分布する。平板な地塊上には, 移 動方向に直行する向きに長軸をもつ長円形の波状の 高まりが連続している。桑沼周辺の凹地上には，先 に述べた巨礫が多数認められる。また波状の高委り の地表面付近は, 未淘汰の安山岩の砂と砂質口ーム で構成される泥流状堆積物が広がっている。

これらの微地形, とくに地塊の規模から判断して, 桑沼地すべり地の主滑落崖は北泉ケ岳第 1 溶岩を切 る崖に対応しているものと考えられる。この崖や前 面の地塊を構成する地質は観察でさなかったが，そ の間に溝状凹地が配列していること, 抢よび崖と地 塊の比高に汪とんど違いがないことなど，地形的に 判断して，断面図に示すよらな直線状のすべり面を 想定した。このすべり面に相当する位置のひとつ, 第 10 図 Loc. 6 の吉田川上流では, 河床が基盤の新鮮な 浮石質凝灰岩で構成されているのが観察される。し かしそれよりやや上部の河床沿いの凝灭岩は破砕さ れ，一部青灰色一灰色に変色し粘土化して招り，す ベり面の一部と考光られる。

以上から桑沼地すべり地の形成プロセスを推定す ると以下のようになる。北泉ケ岳第 2 溶岩を切る崖 は，かつては爆裂火口（小倉，1921）や地すべりに よるもの（寺戸，1978）と考兄られていたが，その 前面に安山岩の巨碟や泥流状堆積物が広がること, 馬蹄形の口を開く方向に位置する王城寺演習場周辺 に流れ山状の地形がみられることなどから，大場他 （1988）が指摘するように，火山の発達過程のなかに みられる山体崩壞によって形成されたものと考光ら
れる。その形成時期は明らかでないが，崖の前面に 広がる泥流状堆積物が, 周辺の最高位段丘の段丘堆 積物々ほぼ氵同一時期のものとされている（北村他， 1984)ことから，数 10 万年前頃と考劣ることはでき る。その後基盤の凝灰岩のある層準をすべり面とし て, 北泉ケ岳第 1 溶岩の堆積面付近から地すべりが 発生した。その過程で地すべり末端の圧縮の場に, 主 に表層部の泥流状堆積物で構成された Pressure ridge が連続して形成されたものと考光られる。

\section{IV。考察}

\section{1. 地すべり地形のタイプと発生条件}

船形山・泉ヶ岳火山のいくつかの地すべりを基に， 形態的特徵や形成プロセスなどで特徵づけられる地 すべり地形のタイプと発生条件について以下に考察 を行う。

船形山・泉ケ岳の地すべり地形には, 白沼, すげ 沼, 桑沼地すべり地などのように山麓部に位置し, 規 模が大きく層すべりで，細かく分化していくタイプ (以下 $\mathrm{A}$ タイプ) と, 大倉山地すべり地のように, 厚 い溶岩などの滑り落ちによって形成された比較的規

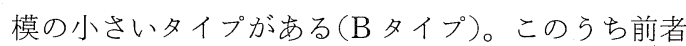
は, 白沼地すべり地のように, 地すべり地形の分化 の過程でも，注とんぞもとの構造が破砝されずに残 るものと(A-1 タイプ), すげ沼や桑沼地すべり地の ように, 移動の過程で, 圧縮の場に本来の構造が変 形，変質，破砕されてできた，Pressure ridgeなど の微地形が形成されるるのに分けられる(A-2 タイ プ)。

第 13 図は, 各タイプの形態的特徵, 地形条件, 地 質条件などを示したものである。A-1 タイプと A-2 タイプは，地形条件・地質条件ともに類似している。 これらの地すべり地形は, 水流による侵食はある程 度進んでいるものの，形状が緩やかで大きな溶岩流 堆積緩斜面に発生している。そのため地すべり地形 の規模も大きい。季た地質条件としては，比較的緩 


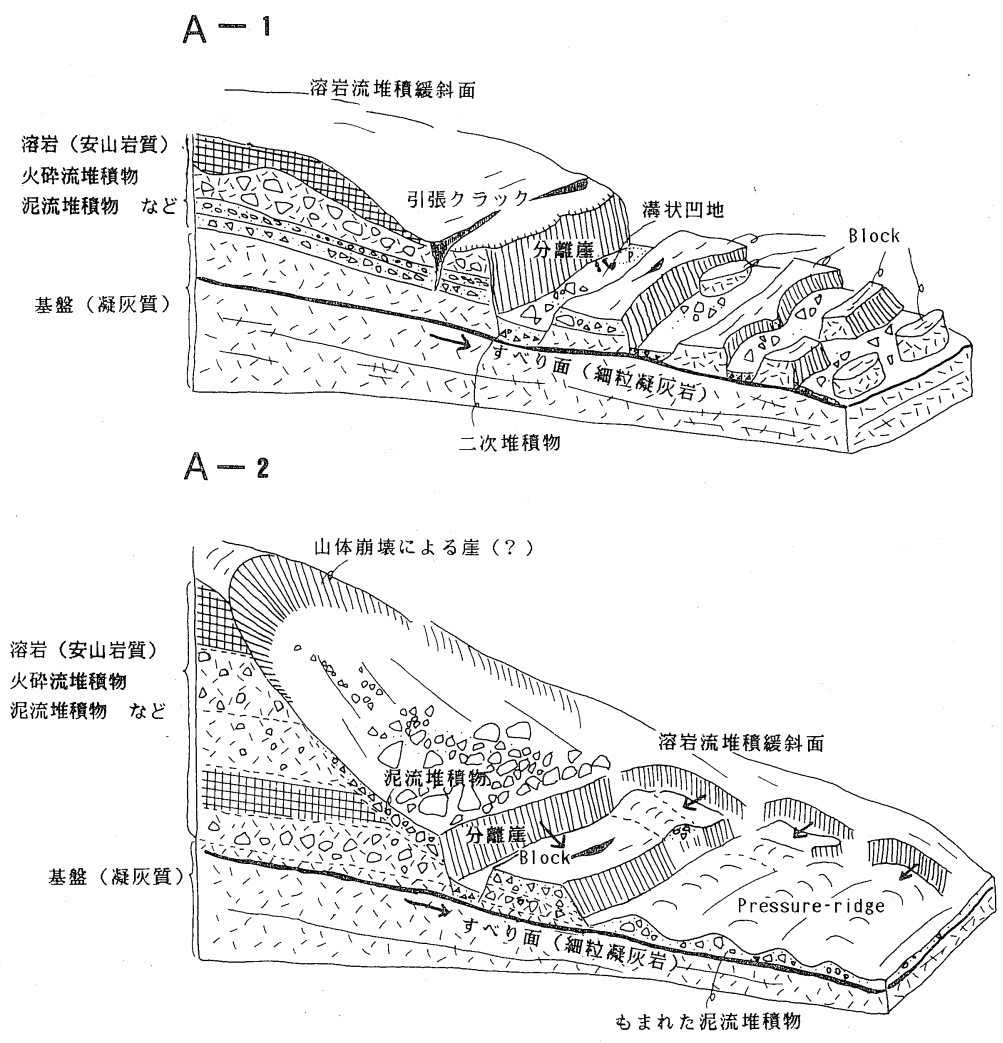

B

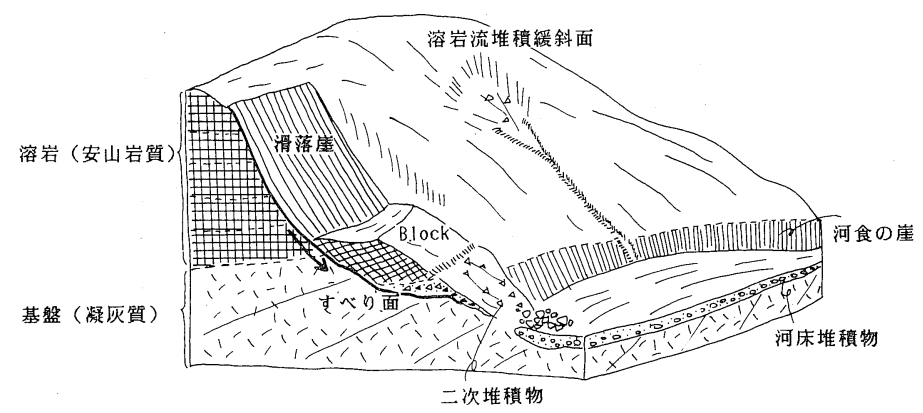

第 13 図 船形山・泉ケ岳周辺の地すべり地形のタイプ

Fig. 13 Landslide types in and around Mt. Funagata and Izumigatake.

傾斜の基盤の上に，火砕流堆積物，溶岩などが載る 構造を示す。それぞれの層厚は 20～ $50 \mathrm{~m}$ 程度であ る。そのほか, 第 1 図 Loc. 1 の菖蒲沼付近でもA タ イプと類似する地すべり地形が観察されており（木 全，1985)，ここでは第三紀層を扣打う約 $50 \mathrm{~m}$ の段 丘礫層の部分から地すべりが発生している。地すべ
り面は，基盤の新第三系の凝灰岩細粒部に観察され ることが多い。A-2 タイプでは, 表層部に比較的 ルーズで未固結な泥流状堆積物などが広がって拉 りこれがもまれて Pressure ridge を形成してい る。その厚さは $10 \mathrm{~m}$ 前後と薄いものである。これら の堆積物は, たと觉ば桑沼地すべり地では, 過去に 
山体崩壊が発生し，その際に泥流状堆積物が供給さ れ，薄く広がったものと考光られる。また先に述べ た菖蒲沼地すべり地では, $50 \mathrm{~m}$ の碩層をもつ古い段 丘面の前面に, 約 $10 \mathrm{~m}$ の厚さの段丘礫層で構成さ れた一段低い段丘面があり,この薄い段丘礫層が, 背 後の地すべりの動きによって圧縮されて Pressure ridge を形成している(木全，1985)。Pressure ridge の形成される位置は, 大規模な Block の前面や, Block の境界部などである。

$\mathrm{B}$ タイプは, 地形的にも地質的にも $\mathrm{A}$ タイプのも のとは異なった場に発生している。これは，地すべ り地形の前面が深い谷で切られていることが多く, 地すべり地形の規模も相対的に小さい。地質的には 基盤の第三紀層の上に柱状節理のはいった溶岩が載 るといら構造を示すが，Aタイプに比べると溶岩が 厚い。このタイプの地すべり地形は, 比較的広範囲 でみられ, 例壳ば第 1 図Loc. 2 の楠峰などもその典 型である。さらに船形山山頂部では, 大倉山地すべ り地と同じょうに, Slumpingによって形成された と考兄られる地すべり地形が認められるが（第 1 図 Loc. 3)，これは複数の Blockによって構成されて拉 り，Bタイプとはやや異なる。このタイプの地すべ り地形については，B タイプの地すべりがより進ん だものなのか，あるいは全く別の系列に属するもの (発生条件が異なる)なのかを明らかにすることが必 要である。

ところで比較的新しい時代の堆積物である基盤の 上に溶岩などがのり，平坦面を形成しているような キャップロック構造をるつ地域に, 地すべりの発生 が多いことは従来より知られて抒り, 長崎県の北松 地域をはじめとして, 東北地方や長野・新潟県など でも多数の例が報告されている（岩塚，1954; 山口 ほか, 1974; 羽田野添か, 1974 など)。基盤の上にの る物質は, 玄武岩や安山岩質の溶岩のみならず，火 砕流堆積物, 碩層, あるいは基盤の風化堆積物であ る岩屑なども含めて叔り，かなり広い範囲にわたっ
ている。このよらな地域に地すべりが多発している 理由としては, 溶岩などの荷重が下の基盤を脆弱化 させるなどが考兄られている。しかし実際には，岩 石のせん断抵抗の值が，地圧がかかっている時とい ない時で異なるといらことがわかっている（山口ほ か，1974）だけで，詳しいことは明らかでない。ま たこのような岩石は,一般に降雨が浸透しやすく,多 量の地下水の供給源となることなど透水性の問題も 注目されている。

先に述べた船形山・泉ケ岳火山周辺の 3 つのタイ プの地すべり地形は，巨視的にみればいずれる キャップロック構造をもつという点では共通してい る。それにもかかわらず地すべり地の形成プロセス や形態的な違いをもたらしたひとつの条件として， このキャップロック構造の載荷岩の種類や厚さの違 いがあると考觉る。載荷岩が溶岩である場合と, 火 砕流堆積物や段丘䃯層などの場合とで, その荷重や 透水性にどの程度の違いがみられ，その結果として 地すべりの発生や形態にどのように反映しているか といったプロセスの解明が今後必要であると考光 る。また表層部に薄く未固結の泥流状堆積物や段丘 礫層などが広がる場合, 圧縮の場に Pressure ridge が形成されることが多く，このことに関しては，表 層部の堆積物がどの程度の厚さであれば, Pressure ridge 形成の条件になりらるかといった問題も重要 であろら。

\section{2. 地すべりの発生時期とその要因}

船形山・泉ヶ岳火山の地すべりの発生時期に関し て,上述した白沼怙よびすげ沼地すべり以外には, 芳 ノ平地すべり地（第 1 図LLoc. 4）に怙いて，地すべ り発生時期が示されている(宮城, 1981)。ここでは 崩壊土砂によって埋積された 2 つ地点に抢ける木 片の年代が，それぞれ 32,000 年前以前 (TH-289), $23,850 \pm 930$ 年前（TH-290）となっている。そして 初期の主要な動きは 32,000 年前以前にあり,2 3 万 年前頃にも二次的あるいは主要な動きがあったとし 
ている。以上のように, 本地域のいくつかの大規模 な地すべりは，地すべり地から得られた ${ }^{14} \mathrm{C}$ 年代值 及びテフラなどからみて, 3 万年前以前に初期の動 きがあり,その後も2 3 万年前执よび 1 万年前以降 にかなり大きな動きがあったことになる。

ところで岩盤地すべりの場合，すべり面は基盤の ある特定の層準に形成され, 地形発達の過程からみ ると,このよらな特定層準が谷底に露出した時に地 すべりの活動が始まると考劣られている（藤田, 1982)。これは初生地すべりの発生に河床レベルの変 動が関与することを示唆しているのであろら。河岸 段丘はある時期の旧河床であることから, 船形山北 麓に発達する鳴瀬川と, その支流青野川および大滝 川の段丘面と地すべり面との層位関係をみた。

第 2 図に示すように，鳴瀬川には，薬萊面，大の 原面, 味ヶ袋面とそれ以下の non-cyclic な面がみら れ, このらち大の原面は堆積性の段丘, 味ヶ袋面は 侵食段丘である（Toyoshima 1986）。下位の味ヶ袋 面の段丘を扣和ら沖積錐堆積物中から得られた木片 の年代が，17,430 土540 $_{580}$ 年前 $(\mathrm{TH}-1170), 21,680 \pm_{890}^{1,000}$ 年前 (TH-1171) といらことから, 味ヶ袋面の離水 は, 約 22,000 年前よりは古いとされている（Toyoshima，1986)。また上位の大の原面は，宮城県北部 に認められる約 45,000 年前の鳴子一柳沢火山灰が のらないことから ${ }^{1)}$ ，その離水時期は 45,000 年前よ りは新しいといらことになる。

鳴瀬川の支流, 青野川上流の白沼地すべり地, 大 滝川沿いのすげ沼地すべり地のすべり面の層準は, 味ヶ袋面の 5〜 $6 \mathrm{~m}$ 程度上位にくる（第 3 図，第 9 図)。大の原面は侵食により失われていることから， 地すべり面との層位関係を直接確認できない。しか 乙両段丘面の比高は上流部覀ど大きくなり，10１5 $\mathrm{m}$ 以上（Toyoshima, 1986）である。したがってす ベり面の層準は, 第 14 図に示すように味ヶ袋面と大 の原面の間にくると予想できる。つまり大の原面が 離水し, さらに下刻されていくある時期（味ヶ袋面

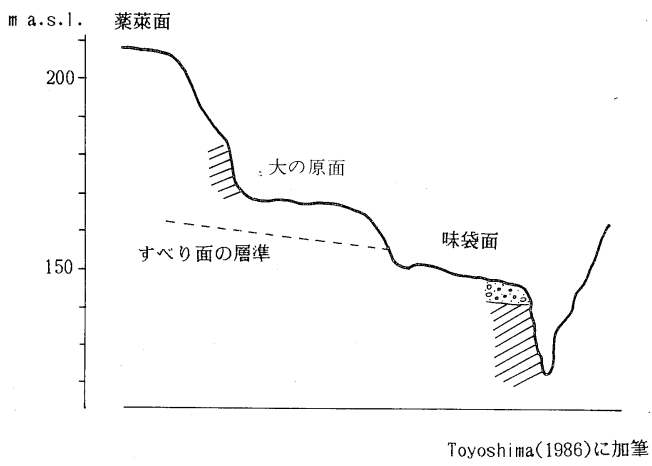

第 14 図 段丘面とすべり面の関係

Fig. 14 Relationship between terrace surface and slip surface layer.

の離水よりは前) に，地すべり地形成の初期の動き があったと考兄られ，その時期は 22,000～45,000 年 前の間といらことになる。また上述したよらに，地 すべり地から直接得られた初期の動きを示す年代值 が，約 3 万年前以前といらことから，船形山。泉ヶ 岳周辺の初生地すべりは, ほぼ3〜4万年前に発生し たことが明らかである。第 15 図は，以上のような本 地域の地すべりの発生時期と周辺の地形発達との関 係をまとめたものである。

3〜4万年前に初生地すべりが発生していること については，次のように考える。すなわら東北地方 では, 地域性はあるものの, 約 10 万年前頃から最終 氷期前半 (約 3,5 万年前以前) に力けて, 河川の中。 上流部で岩屑の生産と供給が行われ, 谷が埋積され た。さらに約 2 5 万年前にかけてそれらが離水し, 堆積段丘が形成された（Toyoshima, 1984, 1986; 山 中・八木, 1987 ; 八木・早田, 1988 ; 渡辺, 1990 他)。 従って 3〜 万年前は谷の埋積から下刻に転じた時 期にあたる。船形山，泉ケ岳山麓でも，和执むねこ の時期に, 鳴瀬川周辺の最終水期の堆積段丘である 大の原面が離水している。また大の原面と味ケ袋面 の間にすべり面が見いだされていることから，河川 の中・上流部で下刻が進み，侵食基準面が変化する ことによって斜面が不安定化し，大規模な地すべり 


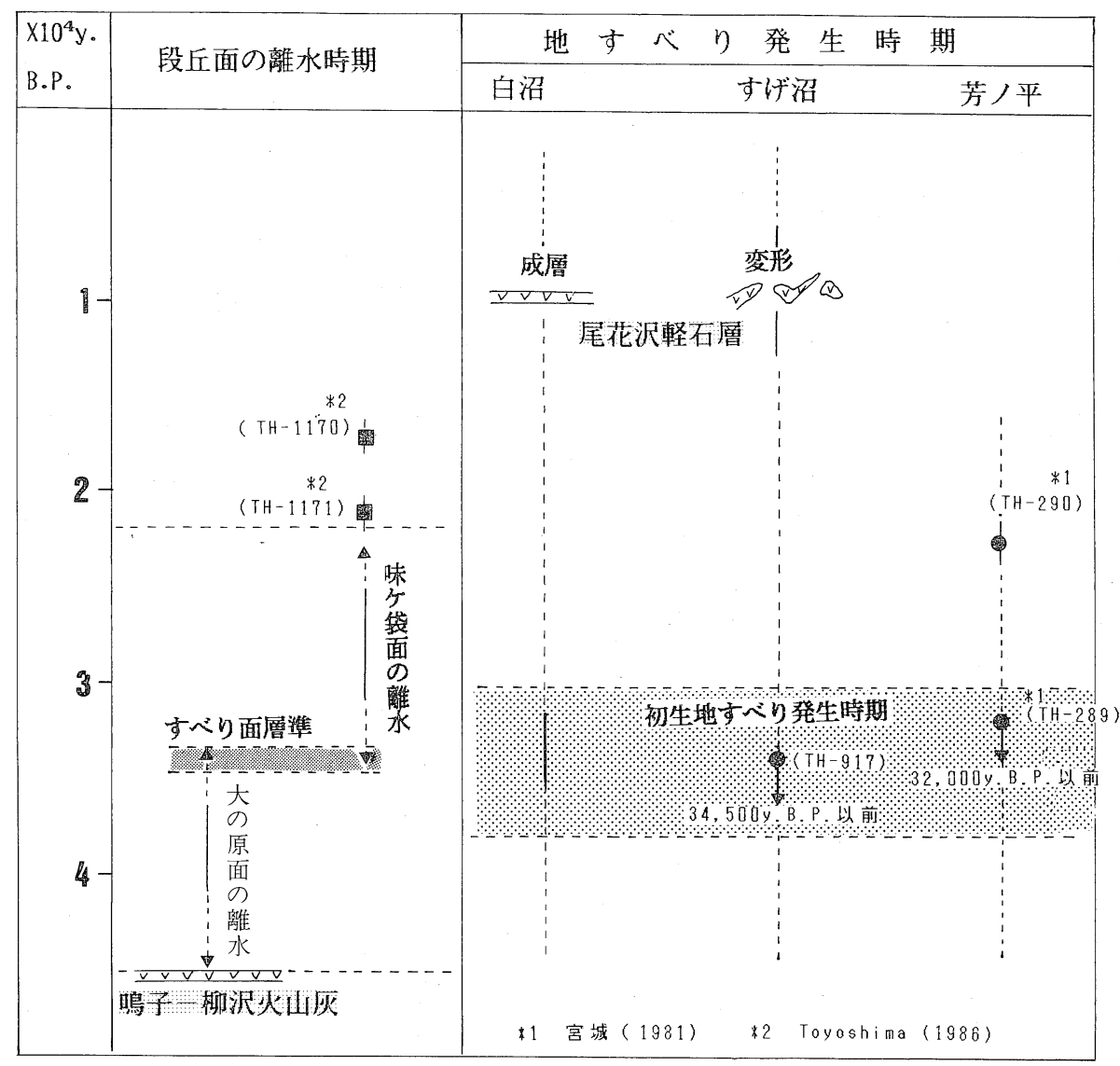

1 2 2 㱐

第 15 図 船形山・泉ケ岳火山周辺の地すべり発生時期と段丘面の離水時期 1 地すべり地の堆積物の ${ }^{14} \mathrm{C}$ 年代 2 段丘上の沖積錐堆積物の ${ }^{14} \mathrm{C}$ 年代

Fig. 15 Occurence age of landslides and emergence age of terrace surface in and around Mt. Funagata and Izumigatake volcanoes.

$1{ }^{14} \mathrm{C}$ ages of deposit in landslide area. $\quad 2{ }^{14} \mathrm{C}$ ages of alluvial cone deposit on the Ajigafukuro terrace surface.

が発生したことが予想される。

一方，地すべりの発生時期に関しては，今までに 公表された ${ }^{14} \mathrm{C}$ 年代值を整理し，「地すべり多発期」 の存在とその要因に関する報告がなされている（宮 城, 1981; 寺川泳か, 1981 ; 大西ほか, 1984 など)。 しかしこれらについては,それぞれの年代資料が, 地 すべり地形発達史を考㝋る上でどのよらな意味をも つ位置から採取されたものなのか，といら吟味が充 分ではないといった指摘がされている(星埜, 1982 ;
古谷ほか，1984; 清水，1985)。またこれらの年代資 料には，初生地すべりに対応するものと，二次移動 に関わるものが混在していると考えられるが，それ らを一括して「地すべり多発期」を論じることにも 無理があると思われる。

地すべりの発生要因については，先に述べたよう な地すべり多発期を, 主に最終水期以降の気候変化 や，それに伴う水理条件や侵食基準面の変化などに 対応するものとして論じられることが多い（寺川ほ 
か, 1981 ; 大西ほか, 1984 ; 清水, 1985 など)。しか 乙最終氷期以降の河川や山地地域の地形発達は必ず しも一様ではなく, 地域や高度など地理的位置に よって異なる。また同じ河川の流域であっても，上 流部と下流部とでは水理条件が異なり，段丘の離水 時期にも差異が認められる（Toyoshima 1984, 1986 など)。従って地すべり多発期と，一般的にいわれて いる最終水期以降の環境変化の時期が対応すること を，そのまま地すべり発生要因に置き換えることに は無理があると思われる。むしろ釜井（1989）など のように，それぞれの地域ごとに，その流域の上流 から下流にかけての地形発達史の中で, 地すべりの 発生時期や発生要因をみていくことが当面の課題で あると考光る。

\section{謝辞}

本論の作成にあたり, 終始御指導頂いた, 東北大学名誉 教授設楽 寬先生, 東北大学米地文夫先生, 田村俊和先 生, 及び東北学院大学宮城豊彦先生飞感謝致します。

本論は, 1983 年に東北大学に提出した修士論文の一部 を, 修正加筆したものであり, 1983 年地すべり学会秥よ び, 東北地理学会 1989 年春季大会に沶いて発表したもの である。

(1990 年 7 月 10 日受理)

\section{注}

1）早田 勉氏私信による

\section{文献}

藤田 崇 (1982)：地すべりの発生年代について。地 すべり技術，9，1３.

古谷尊彦 (1983)：2・3 の火山性大規模地すべりに ついて。第 22 回地すべり学会研究発表予稿集, $40 \sim 41$.

古谷尊彦・宮城豊彦・日比野紘一郎 (1984): 2 ・3 の 地すべり地の年代測定結果について。東北地理, 36, 201 202.

羽田野誠一・岡部文武・渡辺征子 (1974): 北松地域 に扔いて過去に形成された大規模地すべり地形 の一覧表. 防災科学技術総合研究報告, 32,7 $\sim 23$.

星埜由尚（1981）：船形山の地すべり地形。第 20 回
地すべり学会研究発表予稿集, 122１23.

星埜由尚（1982）：ダムサイト適地調查の手法と地

すべり地形の意義。東北地方建設局河川技術資 料.

今田 正・大場与志男 (1989): 船形火山溶岩の K$\mathrm{Ar}$ 年代. 山形県総合学術調查報告「御所山」. 岩塚守公 (1954)：長崎県北部の地すべりととの一

般的特性について. 地理学評論, $27,244 \sim 254$. 釜井俊孝（1989）：長野市西部山地に打けるマス

ムーブメントの発生年代. 第 28 回地すべり学会

研究発表講演集, 36 37.

木全令子（1983）: 東北地方第三紀層地域に発生す

る大規模崩壊の地形学的研究. 東北大学地理学 教室修士論文。

木全令子（1985）: 仙台市西方菖蒲沼付近の大規模

地すべり一微地形分類による運動様式・形成過

程の推定一。拉茶の水地理, $26,10 \sim 17$.

木全令子・宮城豊彦（1985）：地すべり地を構成する

基本単位地形。地すべり，21，1９.

北村 信・大沢 穠・中川久夫 (1983): 吉岡地域の

地質。地域地質研究報告（5 万分の 1 図幅）地

質調查所.

国立防災科学技術センター（1982）: 地すべり地形

分布図。第 1 集。

町田 洋 (1984)：巨大崩壊, 岩屑流と河床変動。地 形, 5, 155 178.

宮城豊彦（1981）：仙台都市圏の地形的基盤一とく

に仙台周辺の古期崩壊地形について一. 東北学

院大学東北文化研究所報告, 12, 176 184.

宮城豊彦・日比野紘一郎・川村智子（1979）：仙台周

辺の丘陵斜面の削剝過程之完新世の環境変化。

第四紀研究，18, 129 143.

守屋以智雄 (1972)：崩壞地形を最小単位にした山 地斜面の地形分類と地形発達. 日本地理学会予

稿集, $2,168 \sim 169$.

守屋以智雄 (1980): 日本の火山地形. 東京大学出版 会。

守屋以智雄 (1985): 空中写真による日本の火山地

形. 東京大学出版会.

守屋以智雄 (1987)：火山体の解体に拈ける大崩壊 の意義. 地形， 8, 67 82.

村山 磐 (1973): 栗駒・船形地域の地形・地質, 栗 駒・船形地域の自然之開発. 東北学院大学東北文 化研究所紀要, 5, 15 24.

西村嘉助・宮城豊彦（1976）: 県立自然公園船形連峰 
の地形及び地質. 県立自然公園船形連峰学術調 查報告書， $2 \sim 24$.

小倉 勉 (1921)：船形火山地質調查報文。震災予防

調査会報告, 93, 1 57.

大場与志男・今田 正・高岡宣雄・佐川 斉 (1988):

船形火山の形成史. 1988 年度日本火山学会講演

予稿集, p. 51

大西吉一・寺川俊浩・西田彰一 (1984): ${ }^{14} \mathrm{C}$ 測定値

からの地すべり多発期について. 第 23 回地すべ

り学会研究発表予稿集, $64 \sim 67$.

大八木規夫（1981）：地すべり。防災科学技術セミ

ナーテキスト，全国防災協会，27〜46.

清水文健（1985）: 東北地方の大規模地すべり地形.

地すべり, 21, 31〜37.

庄司力偉 (1958): 宮城県北西部亜炭田地域の地質.

東北鉱山， $5,1 \sim 25$.

寺戸恒夫 (1978)：奥羽山脈中部の大規模 mass movement. 東北地理, 30, 189 198.

寺川俊浩・白石秀一・西田彰一（1981）：地すべり発 生期の一考察一特に ${ }^{14} \mathrm{C}$ による解析一. 第 20 回 地すべり学会研究発表論文集, 74〜 75.

Toyoshima, M. (1984): The Sequence of River

Terrace Development in the Last 20,000 Years in the Ou Backbone Range, Northeastern Japan. The Science Report of Tohoku University, 7th Series (Geography), 34, 88 $\sim 105$.

Toyoshima, M. (1986): The Downstream Progressing Degradation Since the Würm Stages in the Naruse River Basin, Northeastern Japan. The Science Report of the Tohoku University, 7th Series (Geography), 36, 114 $\sim 125$.

Varnes, D.J. (1958): Landslide Types and Processes. Landslide Engineering practice, H.R.B., Special Report, 29, 20 27.

Varnes, D.J. (1978): Slopes Movement Types and Processes. Landslide Analysis and Control, T.R.B., Spec. Rep., No. 176, 11 33.

渡辺満久 (1990): 北上低地の河成段丘面の編年. 日 本地理学会予稿集, $37,40 \sim 41$.

八木浩司・早田 勉 (1988)：宮城県中・北部に認め られる最終氷期前半の堆積段丘. 日本地理学会 予稿集, $33,28 \sim 29$.

山口真一・中村三郎・中村二郎・栃木省二（1974）：地 すべり・山崩れ一実態と対策一。大明堂.

Yamaguchi, S. ed. (1980): Landslide in Japan. 地すべり学会および地すべり対策協議会。

山中英二・八木浩司 (1987)：飯豊・朝日山地周辺の 河岸段丘の形成一とくに低位堆積段丘について

一. 東北地理, 39, 283 301.

山野井 徹 (1989): 奥羽山系船形山西方の斜面形 成と地すべり。山形県総合学術調查報告「御所 山」.

米地文夫・菊地強一（1966）：尾花沢軽石層につい

て。東北地理, $18,23 \sim 27$.

\section{The Large Landslides since the Last Glacial Age in and around Mt. Funagata and Izumigatake \\ Volcanoes, Northeastern Japan}

\section{Reiko YAGI*}

Mt. Funagata and Izumigatake are strato volcanoes which had mostly developed during the Early and the Middle Pleistocene and then have been mainly denudated by large landslides. In this paper the author reports landslide types which occur in and around volcano, occurence condition and age of landslides in this area, and relationship between occurence age and regional historical development of landforms.

The results are summerized as follows. 
In this area there are two types of landslide. One is a large scale and block-glide type, and the other is comparatively small scale and formed by sliding of thick lava bed and so on. And the former one has also two types. One is remaining its original geological structure uncrushed through process of divide, and the other is crushing its original structure and forming a microlandform, such as pressure ridge. In every case, caprock structure is obserbed. It is thought that one of the factors which results in differences of landslide process and landform in this area is characteristics of caprock, such as variety and thickness of rocks.

Concerning the occurence age of large landslide in this area, the primary activity is estimated about 30,000-40,000 yr. B.P. and secondary one is about 20,000-30,000 yr. B.P.. After 10,000 yr. B.P., a considerable large one occured. During 30,000-40,000 yr. B.P., the latest valleyfilling was replaced by downcutting in river terraces of mountain area of Tohoku district. And large landslide can easily be expected to occur because of change of base level of erosion resulting from violent downwards erosion in midstream and upstream at that time.

${ }^{*}$ Natural History Museum and Institute CHIBA 